\title{
The Swiss Food Net
}

\author{
Jean-Claude Villettaz*
}

\begin{abstract}
The Swiss Food Net was created on March 12, 1999. This national network, to serve the Swiss food industry, unites all institutions of higher education of the food and nutrition sector as well as the main national institutions active in fundamental and applied research. It also incorporates production and processing industry, national scientific communities as well as three federal offices directly concerned with the food sector.
\end{abstract}

Keywords: Educational and research institutions · Food sector · Government offices · Industrial organisations · Scientific communities · Swiss Food Net

\section{The Swiss Food Net}

Contact: Jean-Claude Villettaz, HEVs, Route du Rawyl 47, CH-1950 Sion;

Tel.: +4127606 85 11,

Fax: +41 2760685 15,

E-Mail: jclaude.villettaz@hevs.ch,

http://www.swissfoodnet.ch

Our society is confronted with increasingly complex problems. To solve these problems, more complex skills and multidisciplinary insights and contributions are required - two important reasons for networking!

The new millennium saw the creation of large European research networks and the development of networking. One of the biggest issues will be to achieve an optimal added value of research, as this will allow the expectations of the economy and society to be met in a concrete way.

The food sector is very suitable for networking as it is lies at the interface of life sciences, human sciences and engineering techniques. These networks must not only incorporate raw material producers, food producers and distributors, but should also be accessible to consumer organisations. Today, the food sector must be prepared to listen to the consumers more carefully than ever when they express their uncertainties. Due to an unfortunate series of food safety

${ }^{\star}$ Correspondence: Dr. J.-C. Villettaz

Haute école valaisanne (HEVs)

Route du Rawyl 47

$\mathrm{CH}-1950$ Sion

Tel.: +4127606 8511

Fax: +41276068515

E-Mail: jclaude.villettaz@hevs.ch problems, consumers have developed a certain distrust of industrially processed foods and are very critical of the introduction of new elaboration techniques.

As a result, the success of a food product and, accordingly, of the food sector in general, relies on the dialogue with the consumers in order to regain their trust. Therefore, networks must be visible, sufficiently accessible and willing to listen in such a way that consumers' needs are noted and understood.

The Swiss Food Net fulfils these conditions because of its organisational set-up and the quality of its members. It was created on March 12, 1999. This network unites all institutions of higher education of the food and nutrition sector as well as the main national institutions active in fundamental and applied research. It also incorporates production and processing industry, national scientific communities as well as three federal offices directly concerned with the food sector. Though they are not members of the network as such, consumers can access it via member institutions. The federal offices offer the most obvious access to the network, as their mission is to protect consumer well-being and to safeguard them against possible fraud.

The 14 founder members of Swiss Food Net are:

\section{Industry:}

- Federation of Swiss Food Industries

\section{National Scientific Communities:}

- Swiss Society of Food Science and Technology

- Swiss Society for Food Hygiene
- Swiss Society of Food and Environmental Chemistry

- Swiss Society for Nutrition Research

- Swiss Association of Engineer-Agronomists and Food-Engineers

\section{Educational and Research Institutions:}

- Swiss Federal Institute of Technology in Zürich, Institute of Food Science and Nutrition

- Changins Engineering School, Oenology Department

- University of Applied Sciences of Wädenswil, Food Technology Department

- University of Applied Sciences Bern, Swiss College of Agriculture Zollikofen, Dairy Processing Technology Department

- Haute école valaisanne, Food and Biotechnology Department

\section{Government Offices:}

- Swiss Federal Office of Agriculture

- Swiss Federal Office of Public Health

- Swiss Federal Veterinary Office

The Swiss Food Net's objective is to increase the Swiss food sector's competitiveness by fulfilling consumers' expectations in the best possible way. The network must thus be capable of receiving the messages coming from companies and consumers, making these messages comprehensible and transmitting them to competent partners in order to find a satisfactory solution in a reasonably short time. One of the main qualities of the network and of each of its members must be efficient information flow and processing. A network's value 
is compounded from the quality of its members' contributions, which are shortly described hereafter.

\section{Industry}

\subsection{Federation of Swiss Food Industries}

Fédération des Industries Alimentaires Suisses (FIAL), Foederation der Schweizerischen Nahrungsmittel-Industrien, Federazione delle Industrie Alimentari Svizzere Contact: Beat Hodler, Swiss Food Industry, FIAL, Elfenstrasse 19, Postfach, CH-3000 Bern 16; Tel.: +41 3135211 88, Fax: +4131352 1185 ,

E-Mail: beat.hodler@hodler.ch

Seventeen branch associations of the Swiss food industries are united in the FIAL (Federation of the Swiss Food Industries) as their parent organisation. The FIAL represents 190 firms with about 30000 employees and an annual turnover of 10 billion Swiss francs with an export rate of $17 \%$.

Its main goal is active representation of the interests of the branch, mainly in food legislation, agricultural policy, questions of international integration (WTO), customs regulations, research, and education.

Viewed in a wider sense the Swiss food industry is even more important. The branch represents almost $8 \%$ of all jobs in our industry, with over 2600 establishments and 65000 employees. The structure of these enterprises reach from small craftsman's businesses up to major establishments integrated in multinational companies. Most of the establishments are rather small. Only 600 firms have more than ten employees.

The Swiss food industry performs an important role as:

- a partner of agriculture,

- a supplier to the population,

- an important branch of the national economy.

As a country lacking raw material deposits and with a high degree of dependency on imports in all areas (energy, foodstuffs, steel, etc.) our national economy requires a large volume of exports to provide the necessary means for import financing. Here too the Swiss food industry is making increasingly a substantial contribution by its presence on all export markets.

However it remains the foremost duty of the branch to supply the domestic market (Table 1). The importance of the export business varies widely from branch to branch. Especially oriented towards foreign markets are chocolate, baby food, processed cheese, and soups (Table 2).

The Swiss food industry is well-known for its high quality standards. As an outlook to the future it is essential to maintain and even improve this level. To reach this goal permanent effort and investment in innovation and renewal are of the utmost importance.

\section{National Scientific Community}

\subsection{Swiss Society of Food Science and Technology}

Schweizerische Gesellschaft für Lebensmittel-Wissenschaft und-Technologie (SGLWT), Société Suisse des Sciences et Technologies Alimentaires (SOSSTA)

Contact: Karl Gschwend, SGLWT, Post-

fach 561, CH-8820 Wädenswil

http://www.sglwt.ch

Table 1. Domestic sales in tons

\begin{tabular}{|c|c|c|c|c|c|}
\hline & 2000 [to] & $\begin{array}{l}\% \text { change } \\
\text { from } \\
\text { previous } \\
\text { year }\end{array}$ & $\begin{array}{l}1999 \\
\text { [to] }\end{array}$ & $\begin{array}{l}1998 \\
\text { [to] }\end{array}$ & $\begin{array}{l}1997 \\
\text { [to] }\end{array}$ \\
\hline Cookies, biscuits & 29136 & -1.2 & 29502 & 27350 & 25900 \\
\hline Milk modifiers & 7501 & -0.1 & 7507 & 7604 & 7691 \\
\hline Baby food & 3405 & +3.0 & 3307 & 2440 & 2412 \\
\hline Canned food & 65097 & -7.3 & 70216 & 69339 & 74122 \\
\hline Processed cheese, ready-made fondue & 9434 & -3.7 & 9799 & 9863 & 10051 \\
\hline Chocolate & 74428 & +5.2 & 70743 & 67514 & 68364 \\
\hline Ice cream (in 1000 litres) & 53380 & +6.4 & 50186 & 51461 & 51695 \\
\hline Edible fat \& oil, margarine & 112066 & +0.9 & 111103 & 109029 & 111131 \\
\hline Soups, sauce, seasoning agents & 19372 & -1.3 & 19618 & 20845 & 20390 \\
\hline Pasta & 48965 & -3.5 & 50732 & 50731 & 50335 \\
\hline Sugar confectionery & 8589 & -0.1 & 8596 & 7964 & 8313 \\
\hline
\end{tabular}

Table 1. Exports in tons

\begin{tabular}{lrrrrr} 
& $\mathbf{2 0 0 0}$ [to] $\begin{array}{l}\text { \% change } \\
\text { from } \\
\text { previous } \\
\text { year }\end{array}$ & $\begin{array}{l}\text { 1999 } \\
\text { [to] }\end{array}$ & $\begin{array}{l}\text { 1998 } \\
\text { [to] }\end{array}$ & \multicolumn{1}{c}{$\begin{array}{l}1997 \\
\text { [to] }\end{array}$} \\
\hline Cookies, biscuits & 16866 & +7.0 & 15757 & 13660 & 10631 \\
Milk modifiers & 1407 & -23.8 & 1846 & 1776 & 2450 \\
Baby food & 20286 & +116.6 & 9364 & 11063 & 14586 \\
Canned food & 18095 & +11.5 & 16223 & 14308 & 12900 \\
Processed cheese, ready-made fondue & 10361 & -4.1 & 10808 & 10281 & 10106 \\
Chocolate & 63945 & +6.8 & 59876 & 63429 & 66782 \\
Ice cream (in 1000 litres) & 3780 & +59.9 & 2364 & 2520 & 1419 \\
Edible fat \& oil, margarine & 17016 & +18.9 & 14316 & 12862 & 12812 \\
Soups, sauce, seasoning agents & 33987 & -5.6 & 35990 & 39306 & 39036 \\
Pasta & 8191 & -0.1 & 8198 & 8530 & 8349 \\
Sugar confectionery & 15177 & +2.2 & 14857 & 12901 & 12635
\end{tabular}

The Swiss Society of Food Science and Technology (SGLWT)

- deals with questions and problems of the food product on its way from its agricultural origin and the production process until the product is ready for consumption, and supports research, development and testing,

- supports all efforts being undertaken for the production and presentation of food products of the highest quality,

- supports comprehensive solutions for the optimal public supply of food, taking into consideration the protection of the environment and resources,

- supports further education and encourages mutual contact of its members by organising symposia, round table talks, meetings, and visits of food producing companies,

- maintains close contact to universities, technical institutes and specific training 
schools and contributes the most up-todate knowledge and future aims to the teaching syllabus,

- offers nation-wide publicity concerning specific questions in the field of food production and consumption.

\subsection{Swiss Society of Food Hygiene}

Schweizerische Gesellschaft für Lebensmittelhygiene (SGLH), Société suisse d'hygiène des denrées alimentaires (SSHDA)

Contact: Leo Meile, ETHZ, Institut für Lebensmittelwissenschaft, ETH-Zentrum, CH-8092 Zürich;

E-Mail: leo.meile@ilw.agrl.ethz.ch

The Swiss Society of Food Hygiene (SGLH) is an independent society with a commitment to deal with all specific questions in the field of food hygiene.

The actual number of members of the society is 560 , all working in the wide field of food hygiene such as industrial food production and processing, analytical laboratories, educational and research institutions.

The aim of the society is to support and promote all members in their work and the exchange of knowledge, as well as to encourage activities in education and in the development of studies. For this reason the SGLH holds annual meetings, renowned all over Switzerland, with a topic of the year, and it also organises and supports workshops and professional training of microbiology, molecular biology, and food hygiene. It also organises round-table talks, to which all members and guests are invited, which provide the opportunity to discuss their own problems and general experiences together more thoroughly.

The SGLH, being a founding member of the Swiss Food Net, would like to represent and expand the aims of food hygiene on a wider national and international basis. The Swiss Food Net would be the ideal partner for the exchange of ideas and for the organisation of mutual activities together with other societies such as the Swiss Society of Food Science and Technology (SGLWT), the Swiss Society of Microbiology (SGM) as well as the Swiss Society of Food and Environmental Chemistry (SGLUC).

\subsection{Swiss Society of Food and Environmental Chemistry}

Schweizerische Gesellschaft für Lebensmittel- und Umweltchemie (SGLUC), Société Suisse de Chimie alimentaire et environnementale (SSCAE), Società swizzera di chimica alimentare ed ambientale (SSCAA) Contact: Renato Amadò, ETHZ, Institut für
Lebensmittelwissenschaft, ETH-Zentrum, CH-8092 Zürich,

E-Mail: renato.amado@ilw.agrl.ethz

Food analysis is the main field of interest of the Swiss Society of Food and Environmental Chemistry, but other closely related subjects such as agricultural production, toxicology and food safety and legislation are also included. Its members are actively involved in food control, research, development and teaching, and have a professional background in chemistry, food science, agronomy, and biology or other related sciences. They are specialised in solving analytical problems and are scientists working in food control or environmental laboratories, in the agro-food industry, in federal offices directly involved in production as well as in food control, and in food science and environmental sciences departments of universities.

Food analysis represents the main interest of our society, however, the management of drinking and wastewater, toxicology, hydro-geology and environmental sciences are different facets within our multidisciplinary society.

The activities of the society consist of a general assembly, in which a scientific conference on subjects mainly related to food analysis is integrated. Colloquia for young researchers as well as scientific colloquia related to the different interests of the members of the society have been organised. The topics of last year's conference concentrated on analysis and regulations of wine; the topics for 2002 will focus on problems concerning food-related allergies. In addition, the society plans to both support and to finance scientific activities proposed by members. In early 2002 a survey was carried out to determine the key topics. The numerous answers $(>15 \%$ of the members replied) show the interests of the members and allow an overview on analytical problems closely related to food and environment. The evaluation of the survey has not yet been completed and the decision on this matter will be taken in the near future.

The Swiss Society of Food and Environmental Chemistry is member of the Swiss Academy of Sciences and of the Swiss Chemical Society. Two members of the board are delegates of the national committee of the International Union of Food Science and Technology (IUFoST).

\subsection{Swiss Society for Nutrition Research}

Schwiezerische Gesellschaft für Ernährung $(S G E)$, Société suisse de recherche sur la nutrition (SSRN)
Contact: Hansjörg Ryser, SGE, Effingerstrasse 2, Postfach 8333, CH-3001 Bern; E-Mail: h.ryser@sve.org

The Swiss Society for Nutrition Research (SGE) is a non-profit organisation and its purpose is the promotion of scientific research in the area of nutrition as well as the exchange of information on the latest research projects and results by means of the organisation of scientific events, seminars and symposia; the promotion of research projects; the publication of research projects and their results.

In 2001 SGE counted 210 members (individuals, collective, and honorary members). A new section 'ASERO' (L'association Suisse pour l'étude et la recherche sur l'obésité) was founded and a Task Force was created to promote a Bachelor and/or Master degree in nutrition at ETH Zürich and to improve the teaching of medical doctors in the field of nutrition. A network of 60 science experts have agreed to provide information on relevant nutritional questions.

Public symposia organised or patronised by the Swiss Society for Nutrition Research included 'Dialog über Functional Food zwischen Hochschulen, Industrie, Nationalfonds, Behörden und Wissenschaftsjournalisten', 'Bewegung - Ernährung - Erholung: Einfluss auf die Leistungsfähigkeit', 'Bioavailability 2001', 'Früchte und Gemüse - unerlässlich für die Gesundheit', and 'Molecular-physiological pathways to obesity and metabolic diseases'.

\subsection{Swiss Association of Engineer- Agronomists and Food Engineers}

Schweizerischer Verband der IngenieurAgronomInnen und der Lebensmittel-IngenieurInnen (SVIAL), Association Suisse des Ingénieurs Agronomes et des ingénieurs en Technologie alimentaire (ASIAT)

Contact: Roland Grunder, Landwirtschaftliche Information, Berufsbildung und Beratung, LIB Wülflingen, Riedhofstr. 62, CH-8408 Winterthur;

E-Mail: roland.grunder@vd.zh.ch

As a Swiss professional association, the SVIAL represents the interests of the graduates of the Department of Agricultural and Food Sciences of the Swiss Federal Institute of Technology (ETH) Zürich and other faculties in the same field. It is a member of the ETH Alumni Association.

The SVIAL promotes the permanent education and further training of its members. This is carried out on the one hand through permanent contacts and co-operation with the ETH Zürich and on the other by provi- 
sion of further training opportunities, tailored to requirements, which are organised together with teaching and research institutions (including Swiss Food Net) and with other partners.

\section{Educational and Research Institutions}

In Switzerland, five university-level schools are predominantly working in the food sector. They are all members of the Swiss Food Net:

- Swiss Federal Institute of Technology in Zürich: Institute of Food Science and Nutrition

- University of Applied Sciences of Wädenswil

- University of Applied Sciences Valais: Life Technology

- University of Applied Science, Bern Swiss College of Agriculture, Zollikofen

- Engineering School of Changins.

The common mission of these five institutions is to train engineers in the area of food technology (Zürich, Wädenswil, Sion), dairy economy (Zollikofen) and oenology (Changins). By organising seminars and continuous training courses, they contribute to the continuous updating of technical professionals' know-how and, consequently, to maintaining the competitiveness of our food economy.

On the university level, research and development cannot be separated from training. The Swiss Federal Institute of Technology in Zürich is active in fundamental research and gains added value from its research through development projects. As far as the universities of applied sciences are concerned, they concentrate on applied research and product development. They draw on the acquisitions of fundamental research to develop new products and technologies. Due to their activities in applied research and the services they offer, they are the privileged partners of SME.

The close collaboration between the Institute of Food Science of the Swiss Federal Institute of Technology in Zürich and the four universities of applied sciences constitutes a strong and efficient element for insuring excellent technology transfer and a significant added value for research. This cooperation can also incorporate the federal offices that are highly active in research (Swiss Federal Office of Public Health, Swiss Federal Office of Agriculture, Swiss Federal Veterinary Office etc.).

The concentration of this cooperation potential in a single network such as the
Swiss Food Net leads to a shortening of the distance between research, training and economy and also to an improvement of the quality and efficiency of exchanges and, consequently, of the services of educational and research institutes.

\section{Government Offices}

\subsection{Research Stations of the Federal Office for Agriculture}

Contact: Urs Gantner, Fabio Cerutti, Swiss Federal Office for Agriculture; E-Mail: urs.gantner@blw.admin.ch

The six federal agricultural research stations are attached to the Federal Office for Agriculture; the latter is an Office of the Federal Department of Economic Affairs. The work of the agricultural research stations is geared primarily towards the requirements of government policy. They cover the bulk of public agricultural applied research in Switzerland with a budget of CHF 110 million.

\subsubsection{The Six Agricultural Research} Stations at a Glance

- Swiss Federal Research Station for Agroecology and Agriculture at ZürichReckenholz (FAL)

- Swiss Federal Research Station for Plant Production at Changins (RAC)

- Swiss Federal Research Station for Fruit-Growing, Viticulture, and Horticulture at Wädenswil (FAW)

- Swiss Federal Research Station for Animal Production at Posieux (RAP)

- Swiss Federal Dairy Research Station at Liebefeld-Bern (FAM)

- Swiss Federal Research Station for Agricultural Economics and Engineering at Taenikon (FAT)

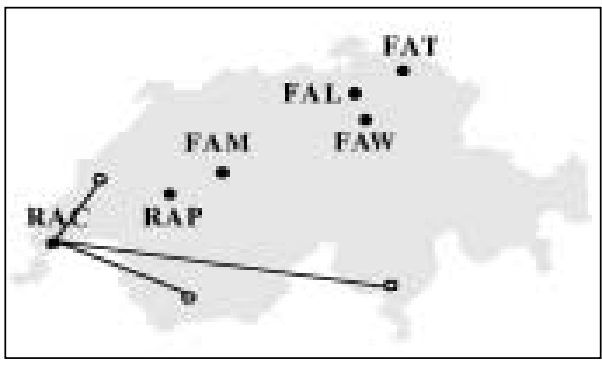

\subsubsection{Research and Legal Tasks}

The guiding principle of the research stations is to act as nationally and internationally recognised institutions for the promotion of multifunctional and sustainable agriculture in Switzerland. To this end, research activities concentrate on the needs of Swiss agriculture and take into considera- tion natural local conditions. The agricultural research stations' activities in the field of applied research take up around 60 percent of the resources.

In addition, the stations carry out homologation, enforcement and control tasks. This makes up about 40 percent of the resources.

\subsubsection{Four Core Areas}

The activities of the agricultural research stations are focused on four core areas:

- Field crops, grassland, and agroecology (FAL and RAC)

- Fruit-growing, wine-growing, and horticulture (RAC and FAW)

- Animal production and food of animal origin (FAM and RAP)

- Agricultural economics and engineering (FAT)

\subsubsection{Six Strategic Targets}

The six agricultural research stations have six strategic targets for the performance period 2000-2003. These are as follows:

- To improve marketability: environmentally sound, quality, animal-welfare and market-oriented agricultural production

- To strengthen the ecological approach: ecosystems/natural resources

- To support socially acceptable structural change: socio-economic developments and rural structures

- To set up an effective early warning system: conservation of natural resources, effect of climate change, global disappearance of biological diversity, globalisation, food production safety, product safety

- To optimise transfer of knowledge: information and documentation

- To promote technical expertise and profiling: concentration on core areas, cooperation and quality

\subsubsection{Businesslike Approach}

The Federal Office for Agriculture favours a businesslike approach in its research. The research stations have operational and financial flexibility. With formal and financial autonomy, an appropriate reporting system is necessary. Indicators and standards have been laid down for the six strategic targets. The performance level of the research stations is measured by indicators associated with their products. This makes it possible to observe and assess target achievement.

\section{Peer Review on Organic Farming}

The peer review method has proven to be an indispensable way of assessing areas of research. In Switzerland organic farming 
has become an important part of agriculture. This has raised the question of whether the research supported by the Federal Office for Agriculture provides sufficient support for this development. The Federal Office has therefore commissioned a group of international experts to look into this question.

The experts recognise that agricultural research in Switzerland has produced important basic information for the introduction of Integrated Production (IP) and that it gives a valuable impetus to organic farming. This research work has put Switzerland in a leading position in organic farming.

\section{The Research Stations Look Ahead}

Precisely in agricultural research, where planning periods are dealt with in four-year cycles, it is becoming important to tackle possible research topics early. In 2000 the Federal Office for Agriculture initiated a so-called Foresight Process. The aim is to draw up a strategy for agricultural research which is as robust as possible for the future. The results of an inquiry among experts and of analysis of scenarios confirm the trend towards more research on food safety and health. So it is only logical in future to take account of the whole process chain in research and control tasks. This also includes topics such as animal welfare and risk management.

Without neglecting previous customers from the agricultural production chain, agricultural research will also concern itself more directly with consumers, and with the environmental and health sectors.

\section{Involvement of Society and Clients}

For the strategic planning of the business unit's activities, the Federal Office for Agriculture has access to advice of the Agricultural Research Council. The Research Council is made up of members who in their professional life deal with questions concerning agriculture, research, the environment, and social policy. This is intended to ensure that long-term research planning takes account of all facets of sustainable development as far as possible.

Each research station can call on a specific Accompanying Group of Experts for its planning and when drawing up concrete projects. The most important customers and partners of the research station in question are represented in these Groups.

\subsubsection{National and International Co-operation}

The agricultural research stations work together with other institutes, universities and institutions abroad. They also offer scientific support for doctoral and post-doc- toral studies. The agricultural research stations publish their results in international scientific journals as well as in publications devoted to practitioners. More information on the Agricultural Research Business Unit and a detailed overview of research projects is available on http.//www.admin.ch/sar.

\subsection{Food Safety, Swiss Federal Office of Public Health}

Contact: Vincent Dudler, Bundesamt für Gesundheit, CH-3003 Bern;

http://www.bag.admin.ch

The legal mandate for Food Safety, a main unit of the Swiss Federal Office of Public Health (SFOPH), is enshrined in the Food Law of 9. October 1992. The overall goals are to protect public health by ensuring the safety of food and articles of daily use, to prevent deception of consumers, and to secure food hygiene.

Food Safety comprises the Food Science Division, which develops scientific and analytical foundations with the support of specialized laboratories, and the Legal Compliance Division, which is responsible for enforcement at federal level.

The main unit's strategy is designed to ensure that the consumption of foodstuffs is safe, with a vision based on confidence, safeguards and individual responsibility.

As a food producer and consumer, Switzerland forms part of Europe and the international community. The unimpeded flow of food imports and exports needs to be ensured by means of harmonized legislation. Key success factors are expertise and effectiveness in dealing with scientific, analytical, technical and legal issues relating to food and articles of daily use. The basic strategic goal is to protect the health of consumers and to prevent deception with the help of precautionary measures and individual responsibility. The main focus of activities is consumer protection conceived of as a preventive health measure. Our strategic goal is to promote and implement coordinated programmes in the areas of legislation and enforcement, as well as carrying out selected programmes in the areas of food/articles of daily use chemistry, microbiology and hygiene, biotechnology, food toxicology and nutrition. For the period 2002-2005, two major priorities in the area of nutrition are as follows:

- Folic acid intake of the Swiss population;

- National project: health and nutrition.

This project is being carried out in cooperation with the Swiss Foundation for Health Promotion.
Food Safety is devoted to the promotion and preservation of human health. It is firmly based within the SFOPH and has close links with other sectors - Health Policy, Epidemiology, Therapeutic Products, Substance Abuse, and Radiation Protection and Chemical Products. Individual responsibility on the part of consumers, together with self-regulatory measures in the production of and trade in food and articles of daily use, is supported by national legal guidelines, which are in line with international legislation. These arrangements facilitate open communication and create fair conditions for trade, commerce and industry.

The Food Science Division provides scientific and analytical foundations in the areas of food and articles of daily use, with the support of laboratories specializing in food chemistry, microbiology and biotechnology. The Food Toxicology Section investigates risks in connection with food toxicology issues raised by the Division and the Main Unit; the Plant Protection Products and Biocides Unit provides expert reports and scientific foundations in the area of plant protection products and biocides and develops a scientific basis for tolerances and limits for chemical residues and additives in food. The Nutrition Unit formulates and implements Swiss nutrition policy and periodically issues the Swiss Nutrition Report.

The Legal Compliance Division is responsible for the enforcement tasks and functions assigned to the federal government.

The Foodstuffs Section is concerned with problems of enforcement relating to foods of animal and plant origin, special foods, and also with non-alcoholic and alcoholic beverages and drinking water.

The Standards and Coordination Section edits the Swiss Food Compendium and the associated explanatory notes, is responsible for law-making activities and coordinates the introduction of national and international standards.

The Articles of Daily Use, Cosmetics and Tobacco Section is concerned with the safety of articles such as toys, textiles and cosmetics, and is responsible for establishing the legal framework for tobacco and smoking-related products.

The International Standards Unit represents Switzerland's interests on the Codex Alimentarius Commission and in other international bodies concerned with the harmonization of food legislation.

Received: May 2, 2002 